\title{
Perhitungan Lampu Penerangan Jalan Berbasis Solar System
}

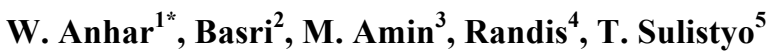 \\ 1,2,3,4, Jurusan Teknik Mesin Politeknik Negeri Balikpapan, Jalan Soekarno-Hatta KM.8 Balikpapan \\ ${ }^{5}$ Jurusan Teknik Sipil Politeknik Negeri Balikpapan, Jalan Soekarno-Hatta KM.8 Balikpapan \\ E-mail: wahyu.anhar@poltekba.ac.id
}

\begin{abstract}
This article is arranged base on community serviceactivities on Pondok Pesantren Darun Nafi KM.34 Samboja Kabupaten Kutai Kartanegara. Community service activities which have been made is assemblies of street-lighting based solar system. Calculation and testing process of street-lighting based solar system is investigated in this article. The specification of street-lighting based solar system is used by 12 Volt of dc lamp, $50 \mathrm{Wp}$ of solar cell, $10 \mathrm{~A}$ of charge control, and 65 Ah of battery. Street-lighting based solar system is used for 12 hours.
\end{abstract}

Keywords:calculation, street-lighting, solar system

\begin{abstract}
Abstrak
Artikel ini disusun berdasarkan kegiatan pengabdian kepada masyarakat (PKM) yang pernah dilakukan di Pondok Pesantren Darun Nafi KM.34 Samboja Kabupaten Kutai Kartanegara. Kegiatan PKM yang dilakukan adalah pemasangan lampu penerangan jalan berbasis solar system. Proses perhitungan dan pengujian lampu penerangan jalan berbasis solar system akan dibahas di dalam artikel ini. Lampu penerangan jalan menggunakan lampu dc 12 Volt, panel surya $50 \mathrm{Wp}$, charge control $10 \mathrm{~A}$, dan battery $65 \mathrm{Ah}$. Lampu penerangan jalan digunakan selama 12 jam.
\end{abstract}

Kata kunci: perhitungan, lampu penerangan jalan, solar system

\section{PENDAHULUAN}

Artikel ini disusun berdasarkan kegiatan pengabdian kepada masyarakat (PKM) yang dilakukan oleh tim PKM Politeknik Negeri Balikpapan. Kegiatan PKM yang dilaksanakan adalah pemasangan lampu penerangan jalan berbasis solar system. Kegiatan PKM dilaksanakan di Pondok Pesantren Darun Nafi KM.34 Samboja Kabupaten Kutai Kartanegara. Penggunaan solar system dalam rangka meningkatkan penggunaan energi baru dan terbarukan (EBT) sebagai pembangkit listrik.

Menurut PP Nomor 22 [1] tentang bauran energi nasional tahun 2015 masih didominasi oleh energi fosil, sedangkan penggunaan EBT masih sangat rendah hanya berkisar 5\%. Gambar 1 menunjukkan persentase bauran energi pada tahun 2015. Selain itu, porsi EBT dalam bauran energi nasional di sektor kelistrikan juga masih sangat rendah, yaitu sebesar $10,5 \%$ dari total produksi [1]. Rendahnya porsi EBT di sektor kelistrikan seperti ditunjukkan dalam Gambar 2.

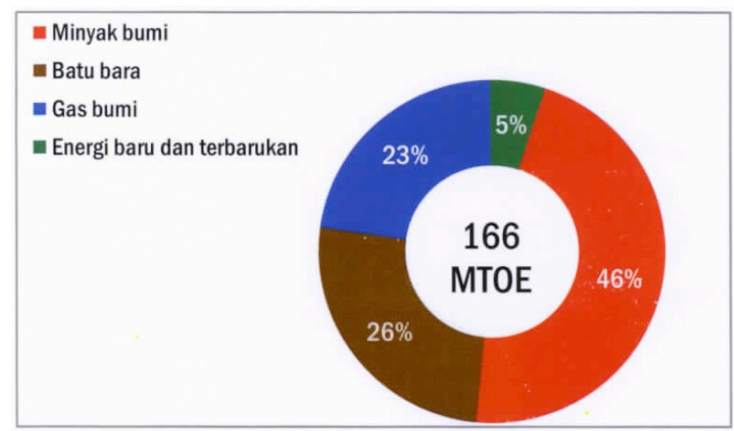

Gambar 1. Bauran Energi Tahun 2015 [1]

Tujuan utama Kebijakan Energi Nasional (KEN) 2050 yaitu Kemandirian dan Ketahanan Energi Nasional. Salah satu prinsip untuk mencapai tujuan utama KEN tersebut adalah memaksimalkan penggunaan EBT [1]. Tenaga surya merupakan salah satu EBT yang harus dimaksimalkan sebagai sumber energi, khususnya pembangkit listrik. Pemanfaatan tenaga surya sebagai pembangkit istrik lampu penerangan jalan ikut memberikan peranan dalam peningkatan penggunaan EBT. Selain itu, Provinsi Kalimantan Timur merupakan urutan ketiga sebagai daerah yang memiliki potensi penyedia tenaga surya [1]. 


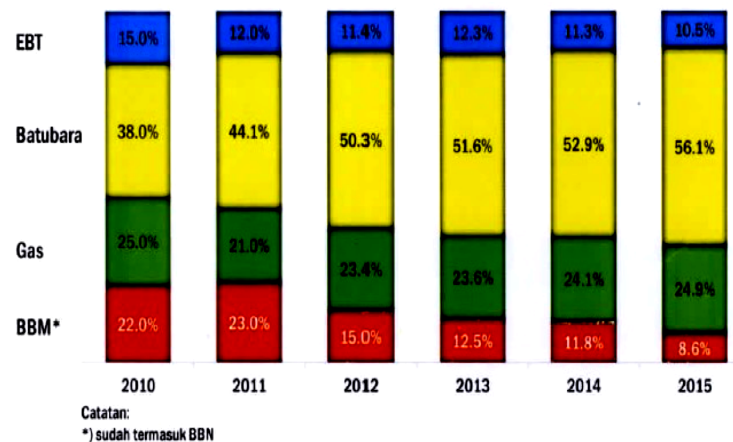

Gambar 2. Bauran Produksi Listrik Energi Tahun 2010-2015 [1]

\section{METODOLOGI}

Guna mewujudkan lampu penerangan jalan berbasis solar system dperlukan beberapa komponen utama, yaitu panel surya, battery, lampu, dan charge control (battery charger regulator).

Panel surya atau photovoltaic panel merupakan komponen yang berfungsi mengubah sinar matahari menjadi energi listrik. Ukuran kemampuan panel surya menggunakan satuan wattpeak (Wp).Menurut [2] perhitungan kapasitas panel surya agar sesuai dengan beban output, dapat menggunakan Pers. (1).

$P_{\text {panel surya }}=\frac{E T}{\text { insolasi matahari }} \times$

1, 1.......Pers. (1)

dimana $P_{\text {panel surya }}$ adalah daya panel (Wp), ET adalah penggunaan daya (Wh), dan insolasi matahari adalah waktu efektif sinar matahari per hari.

Battery adalah komponen yang berfungsi untuk menghasilkan energi listrik arus dc dalam solar system. Energi listrik dalam battery dihasilkan oleh panel surya yang merubah sinar matahari menjadi energi listrik. Ukuran kapasitas battery menggunakan satuan ampere hour (Ah).Merujuk [2] bahwa perhitungan kapasitas battery agar sesuai dengan panel surya dan beban output dapat dihitung dengan menggunakan Pers. (2).

$$
A h=\frac{E T}{v_{S}} .
$$

dimana $A h$ adalah daya battery (Ah), $v_{s}$ adalah tegangan battery yang digunakan (volt).

Selain itu, menurut [2] dalam perhitungan kapasitas battery juga harus mempertimbangkan deep of discharge (DOD) sebesar $80 \%$.Perhitungan kapasitas battery dengan pertimbangan DOD menggunakan hasil Pers (2) yang diinputkan ke dalam Pers. (3).

$$
C b=\frac{A h}{D O D} \ldots \ldots \ldots \ldots . . . \text { Pers. }
$$

dimana $\mathrm{Cb}$ adalah daya battery dengan mempertimbangkan DOD (Ah), Ah adalah daya battery sebelum mempertimbangkan DOD (Ah), dan DOD bernilai $80 \%(0,8)$.

Lampu merupakan komponen yang berfungsi menghasilkan cahaya/penerangan. Jenis lampu yang digunakan adalah lampu dc. Penggunaan lampu dc dikarenakan sistem lampu penerangan jalan yang dibuat tidak menggunakan inventer.

Charge control merupakan komponen yang berfungsi untuk mengatur energi listrik dari panel surya ke battery, dan mengatur energi listrik dari battery ke lampu dc. Charge control merupakan gerbang bagi energi listrik antara panel surya-battery-lampu dc. Penggunaan charge control dalam sistem lampu penerangan jalan menyebabkan energi listrik dari panel surya masuk/mengisi battery, dan menjaga battery tidak mengalami overcharge. Selain itu, charge control menyebabkan energi listrik dari batterytersalurkan ke lampu dc sehingga lampu dc dapat menyala. Pengaturan energi listrik dari battery ke lampu dc dapat diatur oleh charge control, sehingga waktu on/off lampu sesuai dengan waktu yang diinginkan. Ukuran kapasitas charge control digunakan dalam ampere (A). Perhitungan kapasitas charge control menurut [2] dapat dihitung menggunakan Pers. (4).

$$
I_{m a k s}=\frac{P_{m a k s}}{V_{s}}
$$

dimana $I_{\text {maks }}$ adalah kapasitas arus charge control (A), $P_{\text {maks }}$ adalah kapasitas dari panel surya $(\mathrm{W})$, dan $v_{s}$ adalah tegangan panel surya (V).

\section{HASIL DAN PEMBAHASAN}

Lampu penerangan jalan berbasis solarsystem menggunakan output berupa lampu dc dengan daya sebesar 12 Watt, dan pemakaian selama $12 \mathrm{jam} /$ hari. Maka daya yang diperlukan untuk menghidupkan lampu dc per tiap harinya adalah sebesar $144 \mathrm{Wh}$. Lampu dc yang digunakan sebagai sumber penerangan seperti ditunjukkan dalam Gambar 3. 


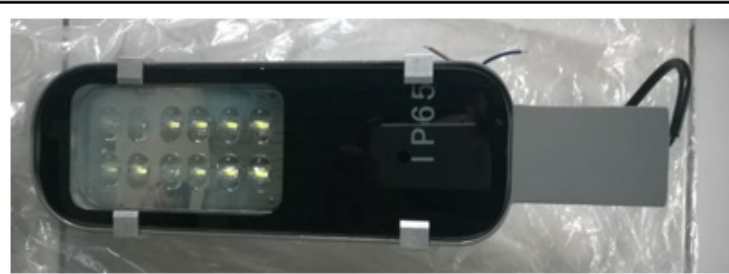

Gambar 3. Lampu dc

Berdasarkan penggunaan lampu dc dengan kapasitas 144 Wh maka diperlukan panel surya dengan kapasitas minimal 31,7 Wp, yang didapatkan dari perhitungan menggunakan Pers (1). Nilai insolasi matahari untuk wilayah Samboja rata-rata berkisar 5 jam. Untuk lebih memaksimalkan pemasukan energi listrik ke battery (penambahan 30\%) guna mengantisipasi insolasi matahari maka digunakan kapasitas 50 Wp. Gambar 4 menunjukkan panel surya yang digunakan dalam lampu penerangan jalan.

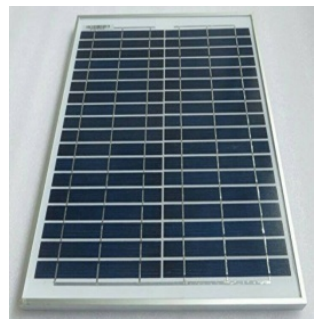

Gambar 4. Panel surya

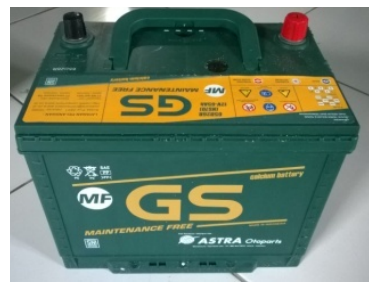

Gambar 5. Battery $65 \mathrm{Ah}$

Kapasitas battery yang diperlukan untuk penggunaan 144 Wh per harinya adalah sebesar 15 Ah, yang dihitung dari Pers. (2), dan Pers. (3). Tetapi berdasarkan kejadian lapangan pernah terjadi 4 hari berturut-turut kondisi mendung, sehingga kapasitas battery dinaikkan menjadi 65 Ah. Battery yang digunakan seperti ditunjukkan dalam Gambar 5.

Charge control yang digunakan berdasarkan kapasitas panel surya $50 \mathrm{Wp}-24$ Volt adalah 10 Ampere. Perhitungan kapasitas charge control menggunakan Pers. (4).Charge control yang digunakan seperti ditunjukkan dalam Gambar 6.

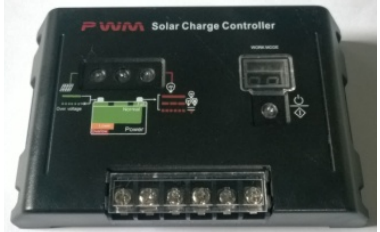

Gambar 6. Charge control

Setelah penentuan spesifikasispesifikasi komponen, selanjutnya dilakukan perakitan, dan pengujian. Penentuan jenis komponen yang akan digunakan juga merujuk pada [3]. Prinsip kerja rangkaian lampu penerangan jalan berbasis solar system menurut [4]seperti ditunjukkan dalam Gambar 7.

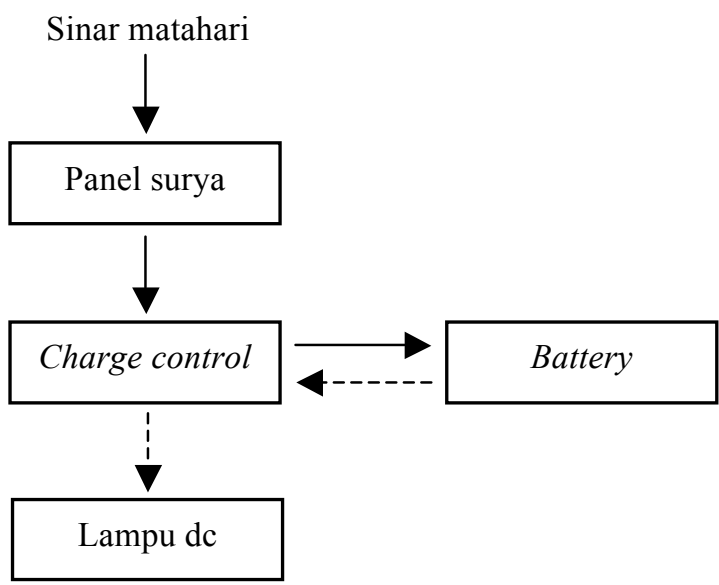

Keterangan:

$\longrightarrow \quad$ : charging ke battery

: output dari battery

Gambar 7. Prinsip kerja rangkaian lampu penerangan jalan berbasis solar system

Prinsip kerja rangkaian lampu penerangan jalan berbasis solar system secara garis besar adalah:

1. Panel surya menangkap sinar matahari yang selanjutnya mengkonversi menjadi energi listrik guna mengisi kebutuhan energi di battery dengan bantuan charge control.

2. Energi listrik dari battery akan digunakan menyalakan lampu dc atas perintah charge control.

3. Waktu mulai penyalaan lampu dc berdasarkan perintah dari charge control ketika panel surya betul-betul tidak mendapatkan sinar matahari (kondisi senja/malam).

4. Lamanya penyalaan lampu dc juga berdasarkan setting pada charge 
control, sehingga penyalaan lampu dapat secara otomatis.

Untuk memastikan bahwa komponenkomponen bekerja secara baik dilakukan pengujian terlebih dahulu. Gambar 8 menunjukkan proses pengujian komponen lampu penerangan jalan berbasis solar system.Gambar 8 (a) menunjukkan pengujian kondisi malam hari. Kondisi malam hari panel surya tidak mendapatkan sinar matahari, maka charge control akan memberikan perintah untuk mengalirkan energi listrik dari batteryke lampu dc sehingga lampu de menyala. Gambar 8 (b) menunjukkan pengujian kondisi siang hari. Ketika siang hari panel surya akan menerima sinar matahari, maka charge control akan mengijinkan energi listrik dari panel surya masuk ke battery, dan memutus energi listrik dari battery ke lampu dc.
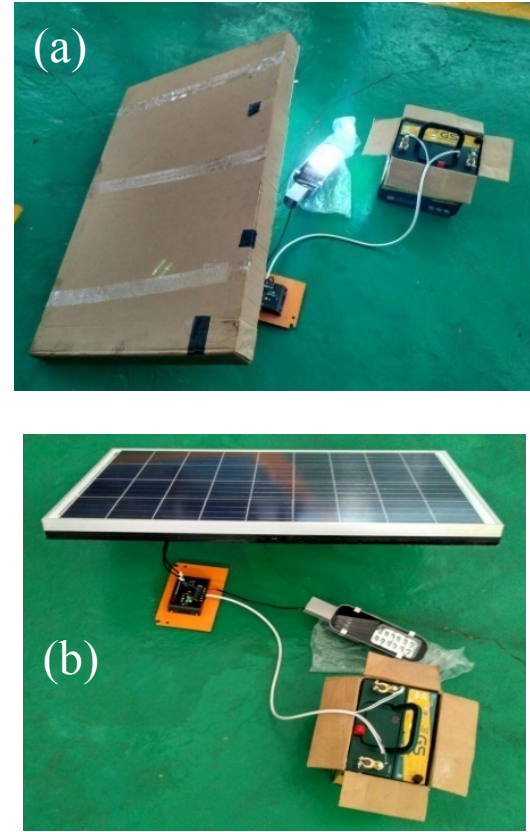

Gambar 8. Pengujian rangkaian kondisi malam hari $(a)$, dan kondisi siang hari $(b)$

\section{KESIMPULAN}

Penggunaan lampu penerangan jalan berbasis solar system merupakan salah satu upaya dalam rangka meningkatkan pemanfaatan tenaga surya sesuai dengan KEN 2050.

Telah dapat dilakukan perhitungan dan pengujian lampu penerangan jalan berbasis solar system yang akan digunakan selama 12 jam. Spesifikasi komponen-komponen adalah panel surya $50 \mathrm{Wp}$, battery $65 \mathrm{Ah}$, charge control $10 \mathrm{~A}$, dan lampu de 12 Volt.

\section{SARAN}

Perlu dilakukan penelitian lebih lanjut terkait insolasi matahari, dan kondisi pancaran sinar matahari per hari, sehingga didapatkan data yang lebih tepat.

\section{UCAPAN TERIMA KASIH}

Artikel ini dapat disusun berdasarkan kegiatan PKM Politeknik Negeri Balikpapan tahun 2017. Kegiatan PKM dapat terlaksana berkat dana pengabdian yang bersumber dari DIPA Politeknik Negeri Balikpapan tahun 2017.

\section{DAFTAR PUSTAKA}

[1] Rencana Umum Energi Nasional, Lampiran I Peraturan Presiden Republik Indonesia Nomor 22, 2017.

[2] Suriadi dan M. Syukri, "Perencanaan pembangkit listrik tenaga surya (PLTS) terpadu menggunakan software PVSYST pada Komplek Perumahan di Banda Aceh," Jurnal Rekayasa Elektrik, vol. 9, no. 2, hal. 77-80, Oktober 2010.

[3] N. S. Kumara, "Pembangkit listrik tenaga surya skala rumah tangga urban dan ketersediaannya di Indonesia," Teknologi Elektro, vol. 9, no. 1, hal 68-75, JanuariJuni 2010.

[4] V. R. Yandri, "Prospek pengembangan energi surya untuk kebutuhan listrik di Indonesia," Jurnal Ilmu Fisika, vol. 4, no. 1, hal. 14-19, Maret 2012. 